J. Japan. Assoc. Min.

Petr. Econ. Geol.

$80,515-525,1985$

\title{
Margarite-paragonite-muscovite assemblages from the low-grade metapelites of the Tono metamorphic aureole, Kitakami Mountains, Northeast Japan
}

\author{
YASUKo OKUYAMA-KuSUNOSE \\ Fuel Geology Department, Geological Survey of Japan \\ Ibaraki, 305, Japan.
}

\begin{abstract}
Margarite occurs in the low-grade zone of the contact aureole of the Tono granitic mass, Kitakami Mountains, Northeast Japan, coexisting with muscovite, paragonite, chlorite and quartz, but without carbonates and feldspars. The margarite is produced by the reaction between pyrophyllite and zoisite in the progressive metamorphism at a temperature near the upper stability limit of the assemblage margarite + quartz. The solubility of muscovite component in paragonite in the three white micas is suppressed as compared to that in the muscovite-paragonite assemblage, whereas the paragonite solubility in muscovite of the three-phase assemblage is similar to that of the two-phase assemblage. Paragonite component in margarite in three-phase assemblage of this area is about $17.3-22.5 \mathrm{~mol} \%$; this value is the smallest for the margarite in threephase assemblages so far reported. The low paragonite solubility of margarite in this area is probably due to the low pressure condition of the contact metamorphism of the Tono area.
\end{abstract}

\section{Introduction}

Margarite, which usually occurs in emery deposit (Aoki and Shimada, 1965) and marble (Jones, 1971 ; Okrush et al., 1976), has recently been described from various metamorphic environments as reviewed by Frey et al. (1982). Many of margarite are of retrograde origin such as pseudomorphs after $\mathrm{Al}_{2} \mathrm{SiO}_{5}$ minerals (Guidotti and Cheney, 1976; Guidotti et al., 1979 ; Atsumi, 1984). However, the formation of margarite clearly defines an isograd in some regional metamorphic terrain (Frey et al., 1982). The occurrence of margarite is important because its stability field is restricted to low temperature and relatively high $a_{\mathrm{H}_{2} \mathrm{O}}$, especially in silica-saturated compositions (Storre and Nitsch, 1974 ; Chatterjee, 1974a, 1976 ; Perkins et al., 1980).

Margarite frequently occurs with pa- ragonite (Ackermand and Morteani, 1973; Enami, 1980 ; Selverstone et al., 1984) and with muscovite (Jones, 1971; Guidotti and Cheney, 1976; Frey, 1978). However, the occurrence of the assemblage of three white micas, which is the low temperature analogue of plagioclasealkali feldspar- $\mathrm{Al}_{2} \mathrm{SiO}_{5}$-quartz assemblage, is scarce (Höck, 1974; Guidotti et al., 1979). Compositions of coexisting two white micas suggest that there is an extensive solid solution on the margarite-paragonite join whereas margarite and muscovite are practically immiscible. However, little is known on the miscibility relations in the three-phase system.

This paper reports the mode of occurrence of margarite in the contact aureole of the Tono granitic mass, the Kitakami Mountains, Northeast Japan, and discusses the miscibility relations in coexisting margarite, paragonite and muscovite.

(Manuscript received, August 1, 1985 ;

accepted for publication, October 24, 1985) 


\section{Geological outline}

The South Kitakami Mountains is mainly occupied by the late Paleozoic sedimentary sequence, which was intruded by numerous granitic bodies of Cretaceous age. The Tono granitic mass, measuring about $40 \mathrm{~km}$ across, is chiefly composed of hornblende-biotite granodiorite with a biotite $\mathrm{K}-\mathrm{Ar}$ age of 117-120 m.y. (Kawano and Ueda, 1965). The contact aureole of the Tono mass is $3-7 \mathrm{~km}$ wide.

In the Miyamori-Ohazama district situated in the northwest of the aureole, Okuyama (1979, 1980) has recognized three mineral zones of progressive metamorphism, namely, the chlorite, andalusite and sillimanite zones (Fig. 1). The chlorite zone, which develops widely in the study area, is further divided into two subzones by the presence or absence of chloritoid in the Al-rich metapelites with molar $X_{\mathrm{Feo}}$ of bulk compositions more than 0.79 (Okuyama, 1980). The assemblage pyrophyllite $+\mathrm{Fe}$-rich chlorite is stable instead of chloritoid $+\mathrm{Fe}$-poor chlorite in the lower chlorite zone;

$$
\begin{gathered}
3 \mathrm{Fe}_{7.2} \mathrm{Mg}_{1.8} \mathrm{Al}_{6} \mathrm{Si}_{5} \mathrm{O}_{20}(\mathrm{OH})_{16}+3 \mathrm{Al}_{4} \mathrm{Si}_{8} \mathrm{O}_{20}(\mathrm{OH})_{4} \\
\mathrm{Fe} \text {-rich chlorite } \quad \text { pyrophyllite } \\
=9 \mathrm{FeAl} \mathrm{SiO}_{5}(\mathrm{OH})_{2}+2 \mathrm{Fe}_{6.3} \mathrm{Mg}_{2.7} \mathrm{Al}_{6} \mathrm{Si}_{5} \mathrm{O}_{20}(\mathrm{OH})_{16} \\
\text { chloritoid } \quad \mathrm{Fe} \text {-poor chlorite } \\
+20 \mathrm{SiO}_{2}+5 \mathrm{H}_{2} \mathrm{O}
\end{gathered}
$$

The andalusite zone is defined by the appearance of andalusite formed by the decomposition of paragonite +quartz in the chlorite zone;

paragonite + quart $z=$ andalusite + albite $+\mathrm{H}_{2} \mathrm{O}$

The transition of andalusite to sillimanite defines the sillimanite zone. The mineral parageneses show the low pressure condition of metamorphism at most $2 \mathrm{kbar}\left(P_{\mathrm{H}_{2} \mathrm{O}}=P_{\text {total }}\right)$.

\section{Petrography}

Two margarite-bearing rocks were discovered from the higher chlorite zone (samples

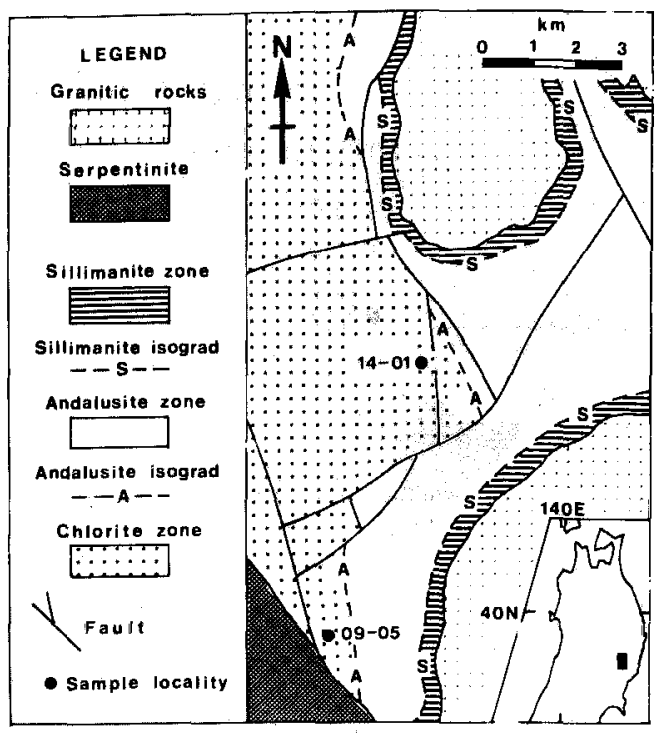

Fig. 1. Mineral zone map of progressive contact metamorphism in the Miyamori-Ohazama district (after Okuyama, 1980) with localities of margarite-bearing rocks.

09-05 and 14-01) (Fig. 1).

Sample $14-01$ is a fine-grained metapelite with greenish gray color and shows weak slaty cleavage. It has the following assemblage; margarite + paragonite + muscovite + chlorite + zoisite + quart $z+$ pyrrotite + sphene + apatite+carbonaceous matter. Under the microscope, margarite, paragonite, muscovite and chlorite occurs as lath-shaped crystals of $5-30 \mu \mathrm{m}$ in width. The sample shows micro. scopic banding structure in which quartzose and micaceous thin laminae are interbedded with each other. Although the proportion of the constituent minerals are different in individual laminae, three white micas form crowded intergrowths with each other. White micas and chlorite generally show weak preferred orientation. Margarite frequently shows a characteristic sheaf-like habit (Fig. 2A). Chlorite associated with white micas is pale gray ripidolite (Hey, 1954) (Table 1). Zoisite occurs as fine-grained granular crystals dispersed among white micas and chlorite. It has 

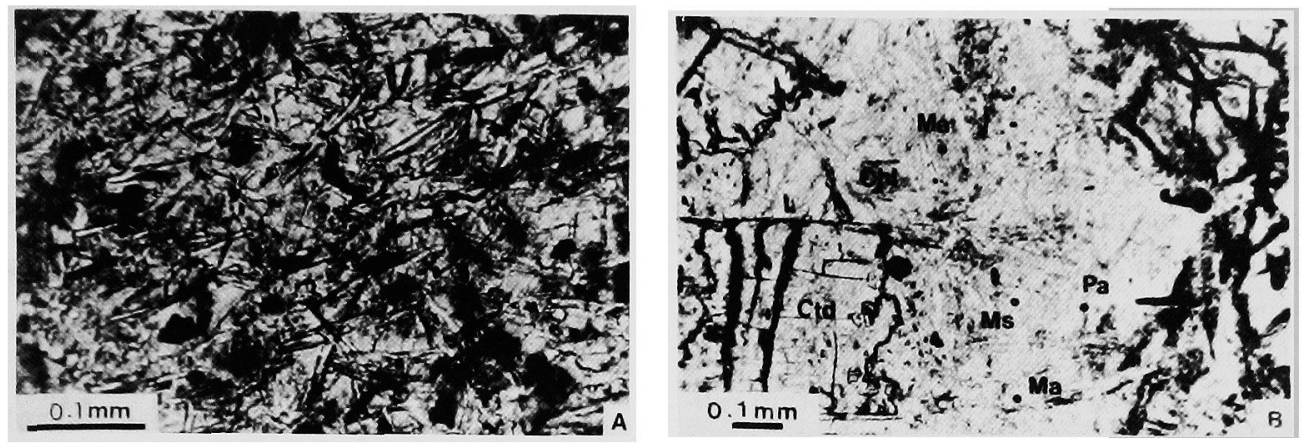

Fig. 2. Photomicrographs of margarite and associated minerals. A) Sheaf-like margarite (high relief) showing weak preferred orientation in sample 14-01. Plane-polarized. B) The association of margarite $(\mathrm{Ma})$, paragonite $(\mathrm{Pa})$ and muscovite $(\mathrm{Ms})$ in chloritoid $(\mathrm{Ctd})$-bearing sample 09-05. Some analyzed points are also shown. Plane-polarized.

Table 1. Microprobe analyses of chlorite, chloritoid and zoisite in margarite-bearing metapelites

\begin{tabular}{|c|c|c|c|c|}
\hline & \multicolumn{2}{|c|}{ Chiorite } & Chloritoid & Zoisite \\
\hline & $\begin{array}{c}14-01 \\
(8)\end{array}$ & $\begin{array}{c}09-05 \\
(9)\end{array}$ & $\begin{array}{c}09-05 \\
(5)\end{array}$ & $\begin{array}{c}14-01 \\
(6)\end{array}$ \\
\hline $\mathrm{SiO}_{2}$ & 23.90 & 23.44 & 24.33 & 39.45 \\
\hline $\mathrm{Al}_{2} \mathrm{O}_{3}$ & 24.07 & 25.11 & 40.22 & 32.53 \\
\hline $\mathrm{FeO}^{*}$ & 30.76 & 32.05 & 26.83 & $1.35^{* *}$ \\
\hline Mno & 0.08 & 0.10 & 0.20 & 0.05 \\
\hline $\mathrm{MgO}$ & 9.98 & 6.15 & 1.22 & $-\ldots$ \\
\hline $\mathrm{CaO}$ & --- & --- & -- & 24.64 \\
\hline Total & 88.79 & 86.85 & 92.80 & 98.02 \\
\hline Si & 5.112 & 5.155 & 1.012 & 3.012 \\
\hline$A I^{I V}$ & 2.888 & 2.845 & -.- & -. \\
\hline$A I^{V I}$ & 3.171 & 3.663 & 1.973 & 2.923 \\
\hline $\mathrm{Fe}^{*}$ & 5.494 & 5.894 & 0.934 & $0.063^{* *}$ \\
\hline $\mathrm{Mn}$ & 0.014 & 0.019 & 0.007 & 0.002 \\
\hline $\mathrm{Mg}$ & 3.179 & 2.016 & 0.079 & -. \\
\hline $\mathrm{Ca}$ & -. - & -.- & -.- & 2.015 \\
\hline Total & 19.859 & 19.592 & 4.005 & 8.015 \\
\hline 0 & 28.0 & 28.0 & 6.0 & 12.5 \\
\hline $\mathrm{Mg} /(\mathrm{Mg}+\mathrm{Fe})$ & 0.367 & 0.255 & 0.078 & $\cdots$ \\
\hline $\mathrm{Fe} /(\mathrm{Al}+\mathrm{Fe})$ & --- & -. & $\ldots$ & 0.021 \\
\hline & 5 & & tal Fe as & $\mathrm{O}_{3}$. \\
\hline
\end{tabular}

Numbers in the parentheses are those of grains analyzed.

low $\mathrm{Mn}$ content and $\mathrm{Fe} /(\mathrm{Fe}+\mathrm{Al})$ ratio $(0.02-$ 0.03) (Table 1).

Sample 09-05 is a black spotted slate with numerous chloritoid porphyroblasts. It has the following assemblage; margarite + para-
Table 2. Unit cell parameters of margarite in sample $09-05$

\begin{tabular}{ccccc}
\hline $\mathrm{a}$ & $\mathrm{b}$ & $\mathrm{c}$ & $\mathrm{B}$ & $\mathrm{v}$ \\
\hline $5.11 \AA$ & $8.83 \AA$ & $19.15 \AA$ & $95.4^{\circ}$ & $860.2 \AA^{3}$ \\
\hline
\end{tabular}

gonite + muscovite + chlorite + chloritoid + quart $z+$ pyrrhotite + sphene + apatite + tourmaline + carbonaceous matter. Its matrix mainly consists of fine-grained margarite, paragonite, muscovite and chlorite. These minerals sometimes form platy crystals about $50-100 \mu \mathrm{m}$ (Fig. 2B). Sheaf-like margarite is also observed. Both fine-grained and platy chlorites are brownish gray ripidolite (Table 1). Chloritoid occurs as isolated prismatic crystals or as rosettes of radiating crystals. It is poor in $\mathrm{Mn}$ and $\mathrm{Mg}$ and lacks noticeable chemical zoning (Table 1).

The presence of margarite was also confirmed by the $\mathrm{X}$-ray powder diffraction. Cell parameters were determined for a margarite condensate from sample 09-05 (Table 2). The values agree well with those of Guggenheim and Baily (1975) that were obtained for well-characterized sample containing comparable paragonite component. 


\section{Chemistry of white micas}

White micas as well as chlorite, chloritoid and zoisite were chemically analyzed using Hitachi electron microprobe X-560S of Tohoku University with an energy dispersive $\mathrm{X}$-ray analyzing system. The analytical method follows Fujimaki and Aoki (1980). White micas were frequently too fine-grained to obtain reliable data. Compositions listed in Table 3 are the average of spot analyses of relatively large platy grains of margarite, paragonite and muscovite.

Although minor $\mathrm{Fe}, \mathrm{Mg}$ and $\mathrm{Ti}$ are neglected, all the mica analyses show slight deviations from the ideal white micas. Step analyses of margarite and paragonite were performed at $5 \mu \mathrm{m}$ interval, but no interlayering was detected.

The amounts of $\mathrm{Na}$ in margarites are equivalent to $17.3-22.5 \mathrm{~mol} \%$ of paragonite solid solution. Total numbers of cations in the octahedral site show small deviation from the ideal ones. This, and the amount of excess $\mathrm{Si}$ as well as the minor contents of $\mathrm{Fe}$ and $\mathrm{Mg}$ indicate that the contribution of other $\mathrm{Na}$ mica components (e.g., Frey et al., 1982 ; Grew and Sandiford, 1984) is negligible to the $\mathrm{Na}$ content of margarite in this locality. $\mathrm{K}$ in margarite and $\mathrm{Ca}$ in muscovite are very low (less than 0.01 atom, on the basis of 22 oxygens), showing negligible solid solution with each other. Margarite and muscovite components in paragonite are $3.2-5.0 \mathrm{~mol} \%$ and $3.8-6.9 \mathrm{~mol} \%$, respectively. Paragonite solid solution in muscovite reaches $11.8-14.3$ mol\%. Small chemical variation in the compositions of these micas suggests that the chemical heterogeneity is not conspicuous.

The amounts of the other elements are very low. Although $\mathrm{Mg}$ and Fe tend to concentrate in muscovite (Table 3), the amount of celadonite molecule does not exceed $15 \mathrm{~mol} \%$.
Table 3. Microprobe analyses of coexisting white micas

\begin{tabular}{|c|c|c|c|c|c|c|}
\hline & \multicolumn{2}{|c|}{ Margarite } & \multicolumn{2}{|c|}{ Paragonfte } & \multicolumn{2}{|c|}{ Muscovite } \\
\hline & $\begin{array}{c}14-01 \\
(6)\end{array}$ & $\begin{array}{r}09-05 \\
(10)\end{array}$ & $\begin{array}{c}14-01 \\
(7)\end{array}$ & $\begin{array}{c}09-05 \\
(5)^{-05}\end{array}$ & $\begin{array}{c}14-01 \\
(5)\end{array}$ & $\begin{array}{c}09-05 \\
(3)\end{array}$ \\
\hline $\mathrm{SiO}_{2}$ & 34.79 & 33.58 & 46.78 & 47.06 & 46.72 & 46.70 \\
\hline $\mathrm{T}^{10} 0_{2}^{2}$ & -- & 0.11 & 0.11 & 0.19 & 0.15 & 0.09 \\
\hline $\mathrm{Al}_{2} \mathrm{O}_{3}$ & 47.43 & 48.51 & 38.97 & 38.85 & 35.74 & 36.05 \\
\hline $\mathrm{FeO} 0^{\star}$ & 0.09 & 0.21 & 0.04 & 0.05 & 0.36 & 0.47 \\
\hline $\mathrm{MgO}$ & 0.16 & 0.18 & 0.12 & 0.22 & 0.82 & 0.72 \\
\hline $\mathrm{CaO}$ & 10.82 & 11.12 & 0.61 & 0.65 & 0.13 & 0.13 \\
\hline $\mathrm{Na}_{2} \mathrm{O}$ & 1.54 & 1.37 & 7.31 & 7.24 & 1.01 & 1.06 \\
\hline $\mathrm{K}_{2} 0$ & 0.11 & 0.10 & 0.60 & 0.61 & 9.83 & 9.92 \\
\hline Total & 94.94 & 95.18 & 94.54 & 94.87 & 94.76 & 95.14 \\
\hline Nur & er of & ations & the ba & $i s$ of 2 & oxygens & \\
\hline si & 4.589 & 4.432 & 6.025 & 6.044 & 6.204 & 6.186 \\
\hline$A I^{I V}$ & 3.411 & 3.568 & 1.975 & 1.956 & 1.796 & 1.814 \\
\hline$A 1^{V I}$ & 3.953 & 3.967 & 3.932 & 3.917 & 3.790 & 3.806 \\
\hline $\mathrm{Ti}$ & --- & 0.011 & 0.011 & 0.018 & 0.015 & 0.009 \\
\hline $\mathrm{Fe}^{\star}$ & 0.010 & 0.024 & 0.004 & 0.005 & 0.040 & 0.052 \\
\hline$M g$ & 0.032 & 0.036 & 0.023 & 0.043 & 0.163 & 0.142 \\
\hline EVI & 3.995 & 4.038 & 3.970 & 3.983 & 4.008 & 4.009 \\
\hline$C a$ & 1.530 & 1.570 & 0.084 & 0.088 & 0.019 & 0.018 \\
\hline $\mathrm{Na}$ & 0.394 & 0.350 & 1.817 & 1.803 & 0.260 & 0.273 \\
\hline k & 0.019 & 0.017 & 0.096 & 0.099 & 1.666 & 1.677 \\
\hline $2 \times I I$ & 1.943 & 1.937 & 1.997 & 1.990 & 1.945 & 1.968 \\
\hline Ca/2XII & 0.787 & 0.811 & 0.042 & 0.044 & 0.010 & 0.009 \\
\hline $\mathrm{Na} / 2 \times 11$ & 0.203 & 0.180 & 0.910 & 0.906 & 0.133 & 0.140 \\
\hline K/2X I I & 0.010 & 0.009 & 0.048 & 0.050 & 0.857 & 0.851 \\
\hline
\end{tabular}

* Total Fe as Feo.

Numbers in the parentheses are those of grains analyzed.

\section{Bulk rock chemistry}

Wet chemical analyses of the two rock specimens described above are given in Table 4 together with the average chemical composition of chlorite zone metapelites containing only muscovite and paragonite as white micas (Okuyama, 1980). Both types of metapelites show following chemical characteristics as compared to the averaged compositions of geosynclinal pelitic rocks (Shaw, 1956 ; Miyashiro and Haramura, 1962); high in $\mathrm{Al}_{2} \mathrm{O}_{3}$ content, ignition loss, molar $\mathrm{Na}_{2} \mathrm{O} /\left(\mathrm{Na}_{2} \mathrm{O}+\mathrm{K}_{2} \mathrm{O}\right)$ ratio, and molar $X_{\mathrm{Feo}}$, and low in $\mathrm{SiO}_{2}, \mathrm{Na}_{2} \mathrm{O}$, $\mathrm{K}_{2} \mathrm{O}$ contents. The chloritoid-bearing sample 05-09 is especially high in $\mathrm{Al}_{2} \mathrm{O}_{3}$ content and $X_{\mathrm{Feo}}$. The principal characteristic of marga- 
rite-bearing rocks is their high $\mathrm{CaO}$ content. Alkali oxides contents in margarite-bearing rocks are lower than those in metapelites of the average chlorite zone, which may also be favourable in the formation of margarite.

\section{Discussion}

\section{Formation of margarite in the Tono contact aureole}

Margarite-bearing rocks in the Tono contact aureole do not show textures that suggest retrograde mineralization. The margarite in the study area is a prograde mineral in the higher chlorite zone.

In the lower chlorite zone of the study area, calcite and zoisite occur sporadically with quartz, muscovite, pyrite or pyrrhotite and carbonaceous matter in the following assemblages ;

$$
\begin{aligned}
& \text { chlorite }+ \text { albite }+ \text { calcite }+ \text { zoisite } \\
& \text { chlorite + paragonite }+ \text { calcite } \\
& \text { chlorite + paragonite }+ \text { calcite }+ \text { albite } \\
& \text { chlorite + paragonite }+ \text { zoisite } \\
& \text { chlorite + paragonite }+ \text { zoisite }+ \text { albite } \\
& \text { chlorite + paragonite }+ \text { zoisite }+ \\
& \text { pyrophyllite }
\end{aligned}
$$

Probably, they are the candidates of the low temperature equivalents of the margarite-bearing assemblages.

These metapelites always contain quartz, sphene, muscovite and carbonaceous matter. The presence of carbonaceous matter and pyrrhotite suggests a low $f_{\mathrm{O}_{2}}$ condition of metamorphism. The $\mathrm{Fe}_{2} \mathrm{O}_{3}$ in zoisite, and $\mathrm{MnO}$ in zoisite and chloritoid are very low and can be ignored. The coexistence of hydrous silicates with calcite and carbonaceous matter suggests the presence of mixed fluid in which $\mathrm{H}_{2} \mathrm{O}, \mathrm{CO}_{2}$ and $\mathrm{CH}_{4}$ are the principal constituents. $\mathrm{CH}_{4}$ probably behave as an inert dilutant and are not important in the discussion of paragenetic relations. Carbonaceous matter is assumed here to be a pure carbon, although it is not a crystalline graphite in the chlorite zone (Okuyama, 1980) and probably includes hydrogen and oxygen. Therefore, the margaritebearing rocks can be treated in the system $\mathrm{Al}_{2} \mathrm{O}_{3}-\mathrm{FeO}-\mathrm{MgO}-\mathrm{CaO}-\mathrm{Na}_{2} \mathrm{O}-\mathrm{C}-\mathrm{H}_{2} \mathrm{O}-\mathrm{O}_{2}$ with excess of quartz, muscovite, sphene, carbonaceous matter and fluid. We further make following two assumptions that $\mathrm{FeO}$ and $\mathrm{MgO}$ are treated as a single component ( $\mathrm{Fe}, \mathrm{Mg}$ ) O and that the fluid in calcic metapelites are $\mathrm{H}_{2} \mathrm{O}$ dominant. The above eight-component volume can be projected to the $\mathrm{Al}_{2} \mathrm{O}_{3}-(\mathrm{Fe}, \mathrm{Mg}) \mathrm{O}-$ $\mathrm{CaO}-\mathrm{Na}_{2} \mathrm{O}$ tetrahedron under these assumptions. The phases considered here in this system are albite $\mathrm{NaAlSi}_{3} \mathrm{O}_{8}$, calcite $\mathrm{CaCO}_{3}$, chlorite $(\mathrm{Fe}, \mathrm{Mg})_{9} \mathrm{Al}_{6} \mathrm{Si}_{5} \mathrm{O}_{20}(\mathrm{O}, \mathrm{H})_{16}$, chloritoid $(\mathrm{Fe}, \mathrm{Mg}) \mathrm{Al}_{25} \mathrm{SiO}_{5}(\mathrm{OH})_{2}$, margarite $\mathrm{Ca}_{2} \mathrm{Al}_{8} \mathrm{Si}_{4} \mathrm{O}_{20}(\mathrm{OH})_{4}$, paragonite $\mathrm{Na}_{2} \mathrm{Al}_{6} \mathrm{Si}_{6} \mathrm{O}_{20}(\mathrm{OH})_{4}$, pyrophyllite $\mathrm{Al}_{4} \mathrm{Si}_{8} \mathrm{O}_{20}(\mathrm{OH})_{4}$, and zoisite $\mathrm{Ca}_{2} \mathrm{Al}_{3} \mathrm{Si}_{3} \mathrm{O}_{12}(\mathrm{OH})$. The treatment of $\mathrm{FeO}$ and $\mathrm{MgO}$ as a single component can be justified because we need not consider the effect of $\mathrm{Fe}_{-}$ $\mathrm{Mg}$ substitution to the paragenetic relation of white micas. The other assumption is not adequate to the calcite-bearing assemblages because relatively high $\mathrm{CO}_{2} / \mathrm{H}_{2} \mathrm{O}$ ratios are expected in the coexisting fluid. However, this does not influence the present discussion because, as is shown below, the margarite in the study is not introduced through reactions involving calcite.

The mineral parageneses of calcic metapelites in the chlorite zone of the study area is schematically illustrated in Fig. 3 . The margarite-forming devolatilization reactions that are possible within the parageneses of the lower chlorite zone (Fig. 3A) are as follows;

5 pyrophyllite +4 zoisite

$$
=4 \text { margarite }+36 \text { quart } z+4 \mathrm{H}_{2} \mathrm{O}
$$

2 paragonite +2 calcite +4 quart $z$

$$
=\text { margarite }+4 \text { albite }+2 \mathrm{H}_{2} \mathrm{O}+2 \mathrm{CO}_{2}
$$




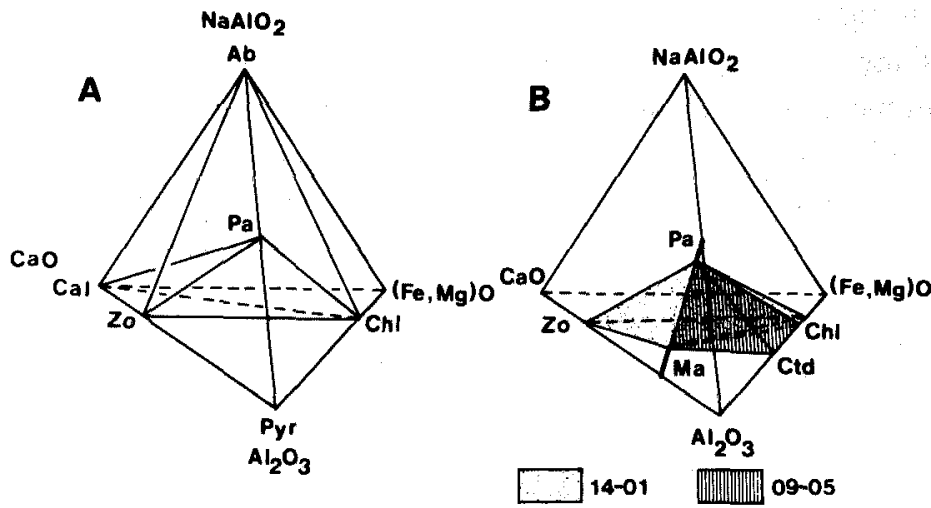

Fig. 3. Paragenetic relations in the calcic metapelites in the lower chlorite zone of the study area (A) and in the margarite-bearing rocks of the higher chlorite zone (B). Mineral abbreviations: Ab, albite; Cal, calcite; Chl, chlorite ; Ctd, chloritoid; Pyr, pyrophyllite; Zo, zoisite.

$$
=4 \text { margarite }+10 \text { albite }+4 \mathrm{H}_{2} \mathrm{O}
$$

Comparing the right-hand sides of these reactions with the mineral parageneses in Fig. 3B, we see that only reaction (3) involves reactant and product assemblages consistent with the natural occurrences in the Tono aureole. Consequently, the margarite-bearing assemblages are formed from the chlorite + paragonite + zoisite + pyrophyllite assemblase. Fig. 3 shows that this assemblage is isochemical with two margarite-bearing assemblages. The figure also shows that the assemblage margarite + paragonite + chlorite + chloritoid is more aluminous than the assemblage margarite+ paragonite + chlorite + zoisite, which is consistent with the bulk chemistry of the specimens containing each paragenesis (Table 4). The Al content of chlorite in sample 09-05 is higher than that in sample 14-01 reflecting the aluminous bulk composition. However, the compositions of margarite, paragonite and muscovite (cf. Table 3 ) are not affected by the difference in coexisting phases. Note that the high $X_{\mathrm{FeO}}$ as well as the high $\mathrm{Al}_{2} \mathrm{O}_{3}$ content is also essential for the calcic metapelites to have chloritoid, as in the case of $\mathrm{Ca}$-poor metapelites (Okuyama, 1980).
Table 4. Chemical analyses of margaritebearing metapelites ( 1 and 2 ) and average chemical composition of margarite-free metapelites in the chlorite zone (3)

\begin{tabular}{|c|c|c|c|}
\hline & 1 & 2 & 3 \\
\hline & $14-01$ & $09-05$ & Av.Ch1.Z \\
\hline $\mathrm{SiO}_{2}$ & 59.97 & 52.14 & 60.70 \\
\hline $\mathrm{TiO}_{2}$ & 1.13 & 1.16 & 1.28 \\
\hline $\mathrm{Al}_{2} \mathrm{O}_{3}$ & 20.90 & 28.43 & 21.88 \\
\hline $\mathrm{FeO} 0^{*}$ & 6.01 & 9.63 & 6.32 \\
\hline MnO & 0.02 & 0.04 & 0.04 \\
\hline $\mathrm{MgO}$ & 1.72 & 1.11 & 1.02 \\
\hline $\mathrm{CaO}$ & 1.50 & 1.63 & 0.11 \\
\hline $\mathrm{Na}_{2} \mathrm{O}$ & 1.07 & 0.56 & 1.63 \\
\hline $\mathrm{K}_{2} \mathrm{O}$ & 1.07 & 0.56 & 1.10 \\
\hline Ig. $10 \mathrm{ss}$ & 5.26 & 3.89 & 5.33 \\
\hline $\mathrm{H}_{2} \mathrm{O}(-)$ & 0.52 & 0.72 & 0.63 \\
\hline Tota 1 & 99.53 & 100.27 & 100.15 \\
\hline${ }^{x} \mathrm{FeO}^{* *}$ & 0.662 & 0.830 & 0.777 \\
\hline $\begin{array}{l}* \text { Total } \mathrm{Fe} \\
* X_{\mathrm{FeO}}=\mathrm{F}\end{array}$ & $\begin{array}{l}\text { Feo. } \\
\text { mol\%/(M }\end{array}$ & mols + & Feo*, mol\%). \\
\hline
\end{tabular}

\section{Temperature of equilibrium}

The reaction (4) has not yet been examined experimentally. Frey (1978) indicated graphically that in the system $\mathrm{Al}_{2} \mathrm{O}_{3}$ FeO-CaO- $\mathrm{Na}_{2} \mathrm{O}-\mathrm{CO}_{2}-\mathrm{H}_{2} \mathrm{O}$ (plus excess muscovite, quart $z$ and fluid) reaction (4) defines a 
low temperature stability limit of margarite at a very low $X \mathrm{CO}_{2}$ condition in the low pressure greenschist facies. He also showed that this reaction takes place at slightly lower temperature than the reaction $(1)^{\prime}$ that produces chloritoid ;

3 pyrophyllite $+2 \mathrm{Fe}$-chlorite

$$
=9 \text { chloritoid }+20 \text { quartz }+5 \mathrm{H}_{2} \mathrm{O}
$$

Hoschek (1969) investigated this Fe-endmember reaction and indicated that the temperature of equilibrium is about $420^{\circ} \mathrm{C}$ at $2 \mathrm{kbar} P_{\mathrm{H}_{2} \mathrm{O}}$. The chloritoid-producing reaction in the study area (reaction (1)) probably occurs at higher temperature than the reaction (1) due to the contribution of the $\mathrm{Mg}$-chlorite molecule in chlorite. Therefore, the temperature of equilibrium of the assemblage chloritoid +chlorite + margarite + paragonite (sample 09-05) is slightly higher than $420^{\circ} \mathrm{C}$. A margarite-free metapelite (sample Nak 154) occuring close to the locality of sample 14-01 contains coexisting muscovite and paragonite with $X_{\mathrm{K}}(=\mathrm{K} / \mathrm{K}+$ $\mathrm{Na}) \quad 0.86$ and 0.06 , respectively (OkuyamaKusunose, in prep.). These compositions give temperature about $450^{\circ} \mathrm{C}$ at $P_{\mathrm{H}_{2} \mathrm{O}}=2 \mathrm{kbar}$ (Eugster et al., 1972). Therefore, the recrystallization temperature of the assemblage margarite + paragonite + muscovite + chlorite + zoisite (sample 14-01) is presumed to be around $450^{\circ} \mathrm{C}$. The temperature suggests that margarite in the Tono aureole was recrystallized near the upper stability limit of margarite +quartz at $2 \mathrm{kbar} P_{\mathrm{H}_{2} \mathrm{O}}$ (Chatterjee, 1976 ; Perkins et al., 1980). Chatterjee (1976) and Perkins et al. (1980) have also discussed that the breakdown of the assemblage of margarite + quartz takes place at lower temperatures than that of paragonite+quartz. The latter reaction defines the andalusite isograd in the Tono aureole as noted before. These stability relations in end member white micas are in harmony with the occurrence of prograde margarite in the chlo- rite zone of the Tono contact aureole. Natural margarite is a solid solution containing other mica components, especially paragonite component (Table 3), and it probably affects the stability of margarite. However, the extent of paragonite solid solution in margarite is limited in the study area as is discussed below.

\section{Miscibility relations in the three white micas}

Coexisting three white micas has also been reported from the Tauern Window, Austria (Höck, 1974) and from the Georgetown area, California (Guidotti et al., 1979). Three white micas in the Tauern Window occur in a pelitic schist of the greenschist facies of the Alpine metamorphism in the following assemblage; margarite + paragonite + phengitic muscovite + chlorite + chloritoid + zoisite + calcite + dolomite+quartz. Those in the Georgetown area occur in the matrix of retrograded metapelites and pseudomorphs after andalusite. Chemical compositions of coexisting three white micas, including those in the Tono aureole, are compiled in Fig. 4.

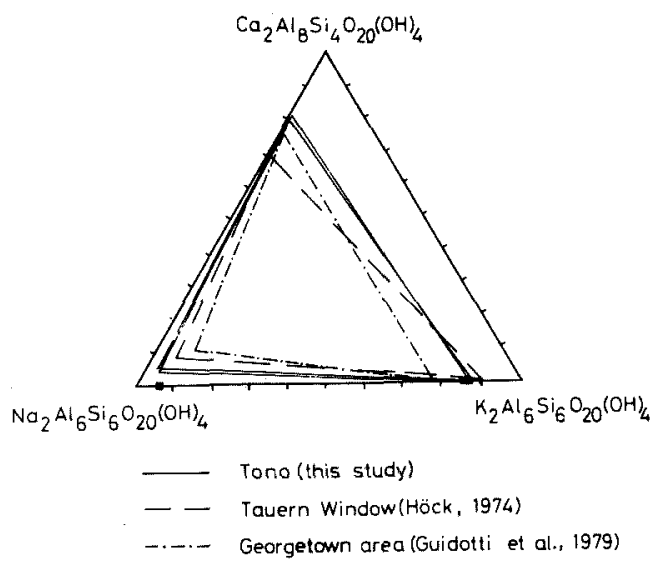

Fig. 4. Compositions of coexisting margarite-paragonite-muscovite in terms of end-member white micas. Bars on the muscoviteparagonite join indicate compositions of coexisting muscovite and paragonite in margarite-free metapelites of the higher chlorite zone of the Tono contact aureole. 
All the three-phase assemblages show almost immiscible relation on the margaritemuscovite join and limited extent of solid solution on the margarite-paragonite and muscovite-paragonite joins. Paragonite in threephase assemblages tends to have lesser amount of margarite component than that of muscovite component. Chemical compositions of coexisting muscovite and paragonite in the higher chlorite zone of the Tono aureole are also shown in Fig. 4. The muscovite component in paragonite is slightly low in the threephase assemblages as compared to those in muscovite-paragonite assemblages. Enami (1980) also showed in the Iratsu amphibolite mass of the high pressure type Sanbagawa metamorphic belt that the muscovite component in paragonite is lower in margarite-bearing rocks than in margarite-free ones. The paragonite solubility of muscovites in the study area is not so different between the three-phase and muscovite-paragonite assemblages (Fig. 4).

The extent of solid solution is different among three localities. Three white micas in the Georgetown area show slightly larger extents of solid solution as compared to those in the Tono aureole. In the Tauern Window, however, the amount of paragonite component in margarite is larger (about $29 \mathrm{~mol} \%$ ) whereas that in muscovite is smaller (about $9 \mathrm{~mol} \%$ ) than those in the Tono aureole and Georgetown area. The low paragonite content in Alpine muscovite may be attributed to its high celadonite content (Enami, 1983; Grambling, 1984). However, compositions of the other white micas considered here are relatively pure with respect to the components other than the end-member muscovite, paragonite and margarite. It is highly probable that the miscibility relation in Fig. 4 manifests the difference in intensive parameter of metamorphism amomg three localities.

Enami(1980) compiled the compositions of coexisting margarite and paragonite from the Iratsu amphibolite mass, Tauern Window (Höck, 1974) and Greiner Schiefer series (Ack-

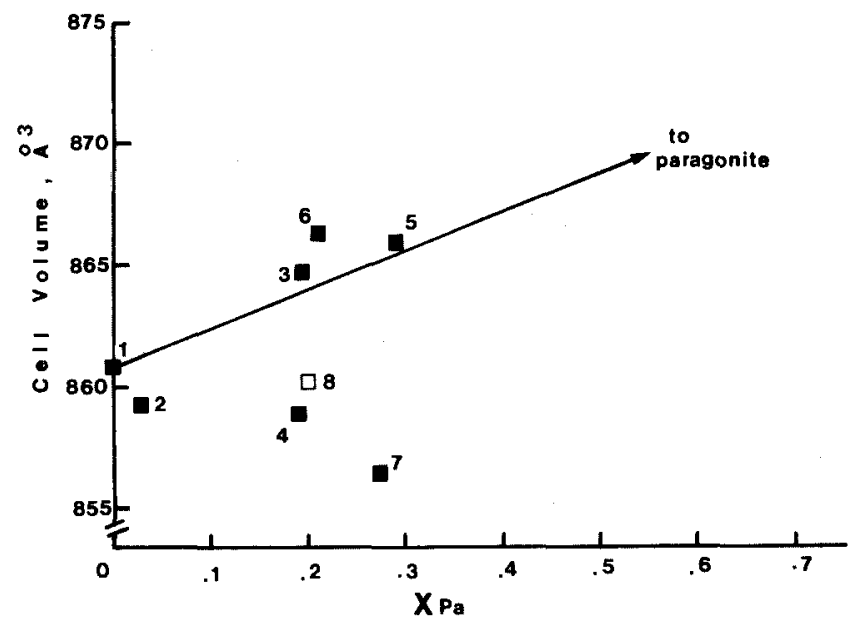

Fig. 5. Irregular cell volume-composition relation of natural margarites. Mixing line joins the synthetic margarite (1, Chatterjee, 1974a) and paragonite (Chatterjee, 1974b). Volume data are from : 2, Aoki and Shimada (1965) ; 3, sample H-148/70 of Höck (1974); 4, Guggenheim and Baily (1975) ; 5, Guidotti and Cheney (1976) ; 6, Guidotti et al. (1979) ; 7, Enami (1980) and 8, present study. Chemical compositions of these margarites indicates that they contain very little amounts of mica components other than margarite, paragonite and muscovite. 
ermand and Morteani, 1973). He pointed out that the compositional gap on the margariteparagonite join lies between 0.51 and $0.84 X_{\mathrm{Na}}(=$ $\mathrm{Na} /(\mathrm{K}+\mathrm{Na}+\mathrm{Ca}))$ in the low grade amphibolite facies and between $0.27-0.29$ and $0.90-0.91 X_{\text {Na }}$ in the greenschist facies. The paragonite content of margarite in the Tono contact aureole is low in comparison with the value inferred from this solvus, if we consider its temperature of equilibrium discussed before. Note that the miscibility relation proposed by Enami (1980) is based on the coexisting margarite and paragonite from the high pressure metamorphic terrains. This strongly suggests that the high pressure condition is favourable in enlarging the solubility limit of margarite toward paragonite. Although the pressure effect on paragonite composition is not clear, the low paragonite content of Tono margarite is probably due to the low pressure condition at this local. ity.

The pressure dependence of the margarite limb of margarite-paragonite solvus inferred from the natural assemblages is consistent with the occurrence of strongly sodic margarite formed in the retrograde stage of some high pressure metamorphic terrains (Grew and Sandiford, 1984 ; Selverstone et al., 1984). Margarite composition can be an important clue to understand the detailed $\mathrm{P}-\mathrm{T}$ paths of metamorphism.

The pressure effect on margarite-paragonite solid solution can be assessed from the volume-composition relation (cf. Waldbaum and Thompson, 1968). However, the available volume data of sodic margarites scatter around the ideal mixing line between synthetic margarite and paragonite (Fig. 5). Guggenheim and Baily (1975) found that some of the natural sodic margarite has tetrahedral layers with AlSi ordering contrary to the other $2 \mathrm{M}_{1}$ white micas. The possible volume change due to the Al-Si ordering should be noted in relation to the complex volume-composition relation on the margarite-paragonite join.

Acknowledgements: I am greatly indebted to Professor K. Aoki of Tohoku University for allowing me to use the electron microprobe facility. Assistance from Dr. T. Yoshida and Mr. M. Nakagawa of Tohoku University, and Dr. M. Murata of Rigaku Denki Co. Ltd. is also grateful. Thanks are due to the staff of the workshop section of the Geological Survey of Japan for the quality of polished thin sections. Valuable suggestions by Dr. T. Nakajima of the Geological Survey of Japan for the early draft of the manuscript is appreciated. I also gratefully acknowledge Professor S. Banno of Kyoto University and Professor H. Onuki of Hirosaki University for their constructive criticism which greatly improved a more final version of the manuscript.

\section{References}

Ackermand, D., and Morteani, G. (1973), Occurrence and breakdown of paragonite and margarite in Greiner Schiefer series (Zillerthal Alps, Tyrol). Contrib. Mineral. Petrol., 40, 293-304.

Aoki, T. and Shimada, N. (1965), Margarite from the Shin-kiura mine, Oita Prefecture. J. Mineral. Soc. Japan, 7, 87-93. (in Japanese)

Atsumi, H. (1984), Finding of margarite in the Ryoke metamorphic rocks from the Kansagawa area, Aichi Prefecture. J. Geol. Soc. Japan, 90, 505-508. (in Japanese)

Chatterjee, N.D. (1974a), Synthesis and upper thermal stability limit of 2M-margarite. Schweiz. Mineral. Petrogr. Mitt., 54, 753-767.

Chatterjee, N.D. (1974b), X-ray powder pattern and molar volume of synthetic $2 \mathrm{M}$-paragonite. Contrib. Mineral. Petrol., 43, 25-78.

Chatterjee, N.D. (1976), Margarite stability and compatibility relation in the system $\mathrm{CaO}$ $\mathrm{Al}_{2} \mathrm{O}_{3}-\mathrm{SiO}_{2}-\mathrm{H}_{2} \mathrm{O}$ as a pressure-temperature indication. Amer. Mineral., 61, 699-709.

Enami, M. (1980), Notes on petrography and rockforming mineralogy (8) Margarite-bearing metagabbro from the Iratsu mass in the Sanbagawa belt, central Shikoku. J. Japan. Assoc. Min. Petr. Econ. Geol. 75, 245-253. 
Enami, M. (1983), Petrology of pelitic schists of the oligoclase-biotite zone of the Sanbagawa metamorphic terrain, Japan; phase equilibria in the highest grade zone of a high-pressure intermediate type of metamorphism. J. Metamor. Geol., 1, 141-161.

Eugster, H.P., Albee, A.L., Bence, A.E., Thompson, J.B., Jr. and Waldbaum, D.R. (1972), The twophase region and excess mixing properties of paragonite-muscovite crystalline solutions. $J$. Petrol., 13, 147-179.

Frey, M. (1978), Progressive low-grade metamorphism of a black slate formation, central Swiss Alps, with special reference to pyrophyllite and margarite bearing assemblages. J. Petrol., 19, 95-135.

Frey, M., Bucher, K., Frank, E. and Schwander, H. (1982), Margarite in the Central Alps. Schweiz. Mineral. Petrogr. Mitt., 62, 21-45.

Fujimaki, H. and Aoki, K. (1980), Quantitative microanalyses of silicates, oxides and sulfides using an energy-dispersive type electron probe. Sci. Rep., Tohoku Univ., Ser. III, 14, 261-268.

Grambling, J.A. (1984), Coexisting paragonite and quartz in sillimanitic rocks from New Mexico. Amer. Mineral., 69, 79-87.

Grew, E.S. and Sandiford, M. (1984), A staurolitetalc assemblage in tourmaline-phlogopitechlorite schist from northern Victoria Land, Antarctica, and its petrologic significance. Contrib. Mineral. Petrol., 87, 337-350.

Guggenheim, S. and Baily, S.W. (1975), Refinement of margarite structure in subgroup symmetry. Amer. Mineral., 60, 1023-1029.

Guidotti, C.V, and Cheney, J. (1976), Margarite pseudomorphs after chiastolite in the Rangeley area, Maine. Amer. Mineral., 61, 431-434.

Guidotti, C.V., Post, J.L. and Cheney, J.T. (1979), Margarite pseudomorph after chiastolite in the Georgetown area, California. Amer. Mineral., 64, 728-732.

Hey, M.H. (1954), A new review of the chlorites. Mineral. Magazine, 30, 277-292.

Höck, V. (1974), Coexisting phengite, paragonite and margarite in metasediments of the Mittlere Hohe Tauern, Austria. Contrib. Mineral. Petrol., 43, 261-273.

Hoschek, G. (1969), The stability of staurolite and chloritoid and their significance in metamorphism of pelitic rocks. Contrib. Mineral. Pet- rol., 22, 208-232,

Jones, J.W. (1971), Zoned margarite from the Badshot formation (Cambria) near Kaslo, British Columbia. Can. J. Earth Sci., 8, 1145-1147.

Kawano, Y. and Ueda, Y. (1965), K-Ar dating on the igneous rocks in Japan II. Granitic rocks in Kitakami Massif. Sci. Rep., Tohoku Univ., Ser. III, 9, 179-215.

Miyashiro, A. and Haramura, H. (1962), Chemical composition of Paleozoic slates IV. Zonal distribution of geosynclinal sediments and the position of regional metamorphic belts. $J$. Geol. Soc. Japan, 68, 75-82. (in Japanese with English abstract)

Okrush, M., Bunch, T.E. and Bank, H. (1976), Paragenesis and petrogenesis of a corundum-bearing marble at Hunza (Kashimir). Mineral. Deposita, 11, 278-297.

Okuyama, Y. (1979), Tono contact metamorphic aureole in the northwestern Miyamori district, Iwate Prefecture, with special reference to low-grade metapelites. M.Sc. thesis, Tohoku Univ., Sendai. (in Japanese)

Okuyama, Y. (1980), Low-grade metapelites in the contact metamorphic aureole around the Tono granodiorite pluton, Miyamori-Ohazama district, Kitakami Mountains. J. Japan. Assoc. Min. Petr. Econ. Geol., 75, 359-371. (in Japanese with English abstract)

Perkins, D. III, Westrum, E.F. and Essene, E.J. (1980), The thermodynamic properties and phase relations of some minerals in the system $\mathrm{CaO}-\mathrm{Al}_{2} \mathrm{O}_{3}-\mathrm{SiO}_{2}-\mathrm{H}_{2} \mathrm{O}$. Geochim. Cosmochim. Acta, 44, 61-84.

Selverstone, J., Spear, F.S., Franz, G. and Morteani, G. (1984), High-pressure metamorphism in the SW Tauern Window, Austria; P-T paths from hornblende-kyanite-staurolite schists. J. Petrol., 25, 501-531.

Shaw, D.M. (1956), Geochemistry of pelitic rocks III. Major elements and general geochemistry. Bull. Geol. Soc. Amer., 67, 919-934.

Storre, B. and Nitch, K.H. (1974), Zur stabilităt von Margarit im System $\mathrm{CaO}-\mathrm{Al}_{2} \mathrm{O}_{3}-\mathrm{SiO}_{2}-\mathrm{H}_{2} \mathrm{O}$. Contrib. Mineral. Petrol., 43, 1-24.

Waldbaum, D.R. and Thompson, J.B., Jr. (1968), Mixing properties of sanidine crystalline solutions II. Calculations based on volume data. Amer. Mineral., 53, 2000-2017. 


\section{北上山地，遠野接触変成帯の低度泥質変成岩のマーガライト \\ ーパラゴナイトーマスコパイト組合せ}

奥山(楠瀬) 康子

北上山地, 遠野花崗質岩体の接触変成帯の低温部では, マーガライトが, マスコバイト・゚ラゴナイト・ 緑泥石・石英と共存して産出する。ここではマーガライトと炭酸塩鉱物及び長石類との共存は認められな い。マーガライトはパイロフィライトとゾイサイトの反応により累進的に生成し, 生成温度はマーガライ ト十石英組合せの高温限界に近かった。白色雲母 3 相共存系でのパラゴナイトのマスコバイト成分固溶量 は，類似の条件においてマスコバイトとのみ共存するパラゴナイトでのそれより低い。しかし，マスコハ イト中のパラゴナイト成分固溶量は両者の間で著しくは異ならない。この地域の白色雲母 3 相共存系での マーガライトのパラゴナイト成分固溶量は 17.3 - 22.5 mol\%で，これ恋で他地域から報告されたものより 小さい。接触変成作用の低圧条件がマーガライトのパラゴナイト成分固溶量を規制している可能性があ る。 